\title{
Nuclear DNA patterns in adrenal cortex proliferative lesions
}

\author{
Salvador Díaz-Cano ${ }^{1}$, Ricardo González-Cámpora ${ }^{1}$, Juan J. Ríos-Martín ${ }^{1}$, Enrique Lerma-Puertas ${ }^{1}$, \\ Mercé Jordà-Heras ${ }^{1}$, Francisco Vázquez-Ramírez ${ }^{1}$, Marluce Bibbo ${ }^{2}$, Hugo Galera-Davidson ${ }^{1}$ \\ ${ }^{1}$ Department of Pathology, University of Seville, Seville, Spain \\ ${ }^{2}$ Department of Cytopathology, University of Chicago, Chicago, USA
}

Received May 19, 1993 / Received after revision July 19, 1993 / Accepted July 28, 1993

\begin{abstract}
In cortical adrenal gland tumours there are discrepancies between morphological criteria for malignancy and biological behaviour. This makes it difficult to select the appropiate treatment. We have studied morphometric and DNA densitometric features of 24 adrenal proliferative lesions (hyperplasia, adenoma, and carcinoma) by means of slide cytometry. All variables have been correlated with pathological diagnosis. The samples were selected from paraffin-embedded tissue, and representative lesions were Feulgen stained. Densitometric study showed aneuploid cell lines in every carcinoma, 5 of 8 adenomas, and 5 of 10 hyperplastic lesions. Both DNA nuclear content (mean ploidy of $2.11 \mathrm{c}, 2.41 \mathrm{c}$, and $3.05 \mathrm{c}$ ) mean nuclear area (average of $31.26 \mu \mathrm{m}^{2}$, $35.92 \mu \mathrm{m}^{2}$, and $42.39 \mu \mathrm{m}^{2}$ ) showed progressive increase from hyperplasia to adenoma, and carcinoma. Mean shape factors were lowest in adenomas (1.69) and highest in carcinomas (1.82). Those karyometric variables which showed statistically significant differences $(p<0.05)$ among diagnostic groups were included in a stepwise three-way discriminant analysis. Only three parameters, shape factor $(p=0.0008)$, mean ploidy $(p=0.0012)$, and adrenal weight $(p=0.0055)$ persisted as independent predictive factors. Using the three variables selected by discriminant analysis on our cases, $100 \%$ of the adenomas were correctly classified, $83 \%$ of the carcinomas, and $80 \%$ of the hyperplasias. Tumour weight and nuclear shape factor differentiated adrenal cortex adenoma from carcinoma, while mean ploidy distinguished adrenal cortical hyperplasia from carcinoma. Nuclear pleomorphism (shape factor) and DNA-ploidy are the most important nuclear features in predicting the biological course of proliferative adrenal cortex lesions, although by themselves they are not bona-fide discriminators.
\end{abstract}

Correspondence to: González Cámpora, Departamento de Anatomía Patológica, Hospital Universitario "Virgen Macarena", Avda. Dr. Fedriani, s/n, E-41009 Sevilla, Spain

\section{Introduction}

Recent advances in molecular genetics suggest that in the initial stage of oncogenesis there is a modification in gene re-ordering which leads to altered gene expression (by mutation or chromosomal translocation), or amplification (Tomasi 1986). For this reason, many studies have been made of nuclear DNA content using flow cytometry or image analysis (static cytometry) (Friedlanders et al. 1984; Dressler and Barton 1989; Seckinger et al. 1989). Initially, aneuploid DNA content was considered to be a specific marker of malignancy and was said to correlate with a more sombre prognosis (Friedlanders 1984; Dressler and Barton 1989). However, later studies revealed aneuploid clonal populations in benign tumours (Joensun et al. 1986; Joensun and Klemi 1988).

In general, there is a correlation between nuclear volume and nuclear DNA content: $15 \%$ of dry weight nuclear mass corresponds to DNA of approximately 5-7 pg (Montironi et al. 1985). Changes in DNA are manifested in nuclear volume and nuclear area, this being the basis for the application of conventional morphometric measurements (nuclear area, perimeter and form factor). These measurements identify classic characteristics of neoplastic cells: pleomorphism, increased nuclear size and nucleus-cytoplasm ratio, loss of polarity, etc. (Baak and Oort 1983).

This study evaluated the morphometric and densitometric features of benign and malignant adrenal cortical lesions to investigate nuclear variables predictive of the biological evolution of the disease.

\section{Materials and methods}

We evaluated 24 cases of adrenal cortex pathology classified by WHO criteria as nodular or diffuse hyperplasia (10 cases), adenoma ( 8 cases), or carcinoma ( 6 cases). All came from the archives of the Department of Pathology of the University of Seville Medical School. We also studied 8 cases of histologically normal adrenal gland (from autopsies) as controls. The material was fixed in $10 \%$ 
buffered formalin and embedded in paraffin following routine processing methods. Representative $4 \mu \mathrm{m}$ thick slices were stained using the Feulgen technique (Deitch 1966) and mounted on Permount. For each case age, sex, follow-up, and morphological features were known (Table 1).

The karyometric study was carried out at the Analytic and Quantitative Cytology Laboratory of the University of Chicago using the MicroTICAS system (Dytch et al. 1986; Puls et al. 1986). At least 100 complete and non-overlapping nuclei in each preparation were quantified. This system permits measurement of integral optical density (extinction) and other cytometric parameters like nuclear area (by the number of pixels occupied by the nucleus) and the nuclear form factor (perimeter ${ }^{2} / 4 \pi$ area). The diploid controls used in all cases were non-activated lymphocytes present in the same preparation; at least 30 nuclei from each preparation were measured. With quantitative variables, the average, the standard deviation and the variation coefficient were selected as representative values of measured cells.

Using the nuclear integral optical density histograms, qualitative and quantitative study were made to identify clonal subpopulations. The corresponding DNA indices were calculated and the cellular proliferation was categorized (Dressler and Barton 1989, Table 2).

Nuclear integral optical density values were used to calculate mean ploidy (as referred to the diploid control, expressed in relative DNA units), the $2 \mathrm{c}$ deviation index $[2 \mathrm{cDI}=\Sigma(\mathrm{Ci}-2 \mathrm{c}) / \mathrm{n}]$, and the percentage of cells with aneuploid nuclear DNA content over $5 \mathrm{c}$ that are not exponent of 2 ( $5 \mathrm{c}$ exceeding rate, $5 \mathrm{cER}$ ) (Böcking et al. 1984; Böcking and Auffermann 1986).

In the statistical analysis the arithmetic mean, standard deviation, and variation coefficient were calculated for all the variables in each pathological group. To establish the significance of differences, the variables obtained for each group were evaluated with the Kruskal-Wallis test. Significant variables $(p<0.05)$ were used for a

Table 1. Adrenal lesions. General features

\begin{tabular}{|c|c|c|c|c|c|c|}
\hline \multirow[t]{2}{*}{ Case } & \multirow[t]{2}{*}{ Diagnoses } & \multirow[t]{2}{*}{ Age } & \multirow[t]{2}{*}{ Sex } & \multicolumn{2}{|c|}{ Follow-up } & \multirow{2}{*}{$\begin{array}{l}\text { Weight } \\
\text { (g) }\end{array}$} \\
\hline & & & & Status & $\begin{array}{l}\text { Time } \\
\text { (months) }\end{array}$ & \\
\hline 1 & Hyperplasia & 25 & $F$ & $\mathrm{AD}$ & 96 & 10 \\
\hline 2 & Hyperplasia & 50 & $\mathrm{~F}$ & $\mathrm{AD}$ & 65 & 94 \\
\hline 3 & Hyperplasia & 39 & $\mathrm{~F}$ & $\mathrm{AD}$ & 63 & 14 \\
\hline 4 & Hyperplasia & 40 & $\mathrm{~F}$ & $\mathrm{AD}$ & 60 & $?$ \\
\hline 5 & Hyperplasia & 62 & $\mathrm{~F}$ & $\mathrm{AD}$ & 48 & 12.5 \\
\hline 6 & Hyperplasia & 23 & $\mathrm{~F}$ & $\mathrm{AD}$ & 24 & 22 \\
\hline 7 & Hyperplasia & 23 & $\mathrm{~F}$ & $\mathrm{AD}$ & 24 & $?$ \\
\hline 8 & Hyperplasia & 38 & $\mathrm{~F}$ & $\mathrm{AD}$ & 15 & $?$ \\
\hline 9 & Hyperplasia & 45 & $\mathrm{~F}$ & $\mathrm{AD}$ & 131 & 6 \\
\hline 10 & Hyperplasia & 53 & $\mathrm{~F}$ & $\mathrm{AD}$ & 123 & $?$ \\
\hline 11 & Adenoma & 57 & $\mathrm{~F}$ & $\mathrm{AD}$ & 96 & 36 \\
\hline 12 & Adenoma & 33 & $\mathrm{~F}$ & $\mathrm{AD}$ & 75 & 7 \\
\hline 13 & Adenoma & 60 & $\mathrm{~F}$ & $\mathrm{AD}$ & 72 & 8 \\
\hline 14 & Adenoma & 49 & $\mathrm{~F}$ & $\mathrm{AD}$ & 36 & 8 \\
\hline 15 & Adenoma & 47 & $\mathrm{~F}$ & $\mathrm{AD}$ & 27 & 14 \\
\hline 16 & Adenoma & 38 & $\mathrm{~F}$ & $\mathrm{AD}$ & 24 & 11 \\
\hline 17 & Adenoma & 41 & $\mathrm{~F}$ & $\mathrm{AD}$ & 24 & 5 \\
\hline 18 & Adenoma & 44 & $\mathrm{~F}$ & $\mathrm{AD}$ & 24 & 7.5 \\
\hline 19 & Carcinoma & 7 & $\mathrm{~F}$ & $\mathrm{AD}$ & 120 & 60 \\
\hline 20 & Carcinoma & 55 & M & DD & 12 & 850 \\
\hline 21 & Carcinoma & 58 & $\mathrm{~F}$ & $\mathrm{DD}$ & 6 & 1320 \\
\hline 22 & Carcinoma & 50 & M & DD & 12 & 20 \\
\hline 23 & Carcinoma & 57 & $\mathrm{~F}$ & DD & 3 & 50 \\
\hline 24 & Carcinoma & 34 & M & $\overline{\mathrm{DD}}$ & 36 & 1110 \\
\hline
\end{tabular}

$\mathrm{AD}$, Alive without evidence of disease; $\mathrm{DD}$, dead related to the disease
Table 2. Classification of cellular proliferation by DNA indices

\begin{tabular}{ll}
\hline DNA index (D.I.) & Ploidy categorization \\
\hline $0.95-1.10$ & Diploid \\
$=(0.95-1.10)$ & Aneuploid \\
$<0.95$ & Hypodiploid \\
$1.10-1.90$ & Hyperdiploid \\
$1.90-2.20$ & Tetraploid \\
$>2.20$ & Hypertetraploid \\
$>2$ D.I. $=(0.95-1.10)$ & Multiploid \\
\hline
\end{tabular}

Modified from Dressler, Bartow (4).

stepwise discriminant analysis; the coefficients of classifying function and the classification matrix were calculated. All mathematical studies were made with the BMDP statistical package.

\section{Results}

Average patient age at the time of diagnosis was 39.8 years $( \pm 12.6$ years $S D)$ for hyperplasia, $43.6( \pm 6.4$ years $\mathrm{SD})$ for adenoma, and 43.5 years $( \pm 18.2$ years SD) for carcinoma. Female ( 21 cases) predominated over males ( 3 cases, all diagnosed histologically as carcinoma). In relation to adrenal weight, a positive finding was clear: minimum weight identified adenomas $(12.1 \pm 10.1 \mathrm{~g} \mathrm{SD})$ and maximum weight carcinoma $(568.3 \pm 594.2 \mathrm{~g} \mathrm{SD})$, with hyperplasia occupying an intermediate position $(26.4 \pm 33.5 \mathrm{~g} \mathrm{SD})$.

The results of conventional morphometry are shown in Table 3. A progressive increment in nuclear area (both mean and standard deviation) is observed from hyperplasia to carcinoma; the nuclear form factor exhibits a trend similar to adrenal weight distribution.

Analysis of nuclear integral optical density histogram led to individualization of 27 clonal subpopulations with DNA indices from 0.88 to 1.88 . Only 3 cases had 2 subpopulations ( 2 adenomas and 1 carcinoma); 20 cases had only one subpopulation. The remaining histogram was aneuploid but unclassifiable.

Mean DNA index of the clonal populations identified was 0.98 for hyperplasia (0.88-1.10 range), 1.31 for adenoma (1.00-1.88 range) and 1.39 for carcinoma (1.00-1.88 range). Each lesion was characterized: 8 were diploid, 3 aneuploid with a diploid subpopulation, and 12 aneuploid without a diploid subpopulation. One case of carcinoma showed an aneuploid histogram without demonstrating a predominant cellular population (Table 4). In none of the cases was polyploidization, multiploidization, or a tetraploid cell population observed. Table 3 summarizes the results of cytomorphometry (mean ploidy, 2cDI, and 5cER). A progressive increment in all these parameters from hyperplasia to carcinoma is apparent.

The Kruskall-Wallis test showed statistically significant differences among the three groups (hyperplasia, adenoma, and carcinoma) with the following variables: adrenal weight $(p=0.0055)$, mean nuclear area $(p=0.0118)$, mean nuclear form factor $(p=0.0008)$, stan- 
Table 3. Morphometric and DNA densitometric nuclear results in proliferative adrenal lesions

\begin{tabular}{|c|c|c|c|c|c|c|c|c|c|}
\hline \multirow[t]{2}{*}{ Variables } & \multicolumn{3}{|c|}{ Hyperplasias } & \multicolumn{3}{|c|}{ Adenomas } & \multicolumn{3}{|c|}{ Carcinomas } \\
\hline & Average & S.D. & C.V. & Average & S.D. & C.V. & Average & S.D. & C.V. \\
\hline Area (average) & 31.257 & 6.995 & 0.224 & 35.920 & 6.417 & 0.179 & 42.385 & 5.511 & 0.130 \\
\hline Form factor (average) & 1.715 & 0.019 & 0.011 & 1.689 & 0.020 & 0.012 & 1.822 & 0.081 & 0.045 \\
\hline Form factor (S.D.) & 0.148 & 0.026 & 0.178 & 0.128 & 0.018 & 0.144 & 0.200 & 0.041 & 0.205 \\
\hline Ploidy (average) & 2.113 & 0.259 & 0.123 & 2.413 & 0.197 & 0.082 & 3.048 & 0.493 & 0.162 \\
\hline $5 \mathrm{cER}$ & 0.585 & 0.907 & 1.550 & 1.629 & 1.737 & 1.067 & 11.060 & 8.137 & 0.736 \\
\hline
\end{tabular}

S.D., Standard deviation; C.V., coefficient of variation; $2 \mathrm{cDI}, 2 \mathrm{c}$ deviation index; $5 \mathrm{cER}, 5 \mathrm{c}$ exceeding rate

Table 4. DNA ploidy category distribution in cases of proliferative adrenal lesions

\begin{tabular}{|c|c|c|c|}
\hline Ploidy & $\begin{array}{l}\text { Hyperplasias } \\
\text { No. (\%) }\end{array}$ & $\begin{array}{l}\text { Adenomas } \\
\text { No. (\%) }\end{array}$ & $\begin{array}{l}\text { Carcinomas } \\
\text { No. (\%) }\end{array}$ \\
\hline Diploid & $5(50)$ & $3(37.5)$ & - \\
\hline $\begin{array}{l}\text { Aneuploid } \\
\quad+\text { diploid subpopul. } \\
\text { - diploid subpopul. }\end{array}$ & $-5(50)^{\mathrm{c}}$ & $\begin{array}{l}2(25)^{\mathrm{b}} \\
3(37.5)^{\mathrm{b}}\end{array}$ & $\begin{array}{l}1(20)^{b} \\
4(80)^{b}\end{array}$ \\
\hline Total & $10(100)$ & $8(100)$ & $5(100)^{d}$ \\
\hline
\end{tabular}

a Based on Dressler, Bartow (4)

b All aneuploid cellular subpopulations were hyperdiploid

c All cases were hypodiploid

d One case of carcinoma showed an aneuploid histogram without identifying a predominant cellular population
Table 6. Classification matrix after applying discriminant function in proliferative adrenal lesions

\begin{tabular}{|c|c|c|c|c|}
\hline \multirow{2}{*}{$\begin{array}{l}\text { Working group } \\
\text { (W.H.O.) }\end{array}$} & \multirow{2}{*}{$\begin{array}{l}\text { No. of } \\
\text { cases }\end{array}$} & \multicolumn{3}{|c|}{ Predictive group } \\
\hline & & $\begin{array}{l}\text { Hyperplasias } \\
\text { (A) }\end{array}$ & $\begin{array}{l}\text { Adenomas } \\
\text { (B) }\end{array}$ & $\begin{array}{l}\text { Carcinomas } \\
\text { (C) }\end{array}$ \\
\hline Hyperplasias (A) & 10 & $\begin{array}{c}3 \\
80 \%\end{array}$ & $\begin{array}{c}2 \\
20 \%\end{array}$ & $\begin{array}{l}0 \\
0 \%\end{array}$ \\
\hline Adenomas (B) & 8 & $\begin{array}{l}0 \\
0 \%\end{array}$ & $\begin{array}{c}8 \\
100 \%\end{array}$ & $\begin{array}{l}0 \\
0 \%\end{array}$ \\
\hline Carcinomas (C) & 6 & $\begin{array}{c}1 \\
17 \%\end{array}$ & $\begin{array}{l}0 \\
0 \%\end{array}$ & $\begin{array}{c}5 \\
83 \%\end{array}$ \\
\hline
\end{tabular}

Percent of cases correctly classified: $90 \%$
Table 5. Independent predictive variables in proliferative adrenal lesions with their corresponding classification functions

\begin{tabular}{lccr}
\hline Variables & Group A & Group B & \multicolumn{1}{c}{ Group C } \\
\hline $\begin{array}{l}\text { Form factor (average) } \\
\quad \text { (adimensional) }\end{array}$ & 2756.428 & 2664.596 & 2917.641 \\
$\begin{array}{l}\text { Ploidy (average) } \\
\text { (relative units) }\end{array}$ & -199.451 & -189.272 & -204.101 \\
$\begin{array}{l}\text { Adrenal weight (average) } \\
\text { (grames) }\end{array}$ & 0.295 & 0.284 & 0.316 \\
$\begin{array}{l}\text { Constant } \\
\text { (adimensional) }\end{array}$ & -2157.874 & -2024.422 & -2437.333 \\
\hline
\end{tabular}

dard deviation of the nuclear form factor $(p=0.0052)$, mean ploidy $(p=0.0012)$, standard deviation of the ploidy $(p=0.0024), 2 \mathrm{cDI}(p=0.0012), 5 \mathrm{cER}(p=0.0009)$, and the lowest $(p=0.0108)$ and highest $(p=0.0023)$ DNA indices for each case.

Significant variables $(p<0.05)$ were evaluated by discriminant analysis. Mean nuclear form factor, mean ploidy, and mean adrenal weight retained independent predictive value. The eight other variables that were significant in unvariate analysis lost their value in multivariate study.

The stepwise three-way discriminant analysis yielded the classification function shown in Table 5 and the classification matrix in Table 6 . Using the three variables selected by discriminant analysis on our study cases, $100 \%$ of the adenomas were correctly classified, $83 \%$ of the carcinomas, and $80 \%$ of the hyperplasias.
New cases can be assigned to the group for which the largest global discriminant function score was obtained, with a probability of accuracy of $90 \%$ if: (a) the three diagnostic conditions (hyperplasia, adenoma, carcinoma) occurred in equal proportions and (b) we used the selected variables and classification function as we did. Each global discriminant function score (in groups $A, B$ and $C$ ) is obtained multiplying the numeric value of every variable by its corresponding particular score.

\section{Discussion}

In adrenal pathology, as in most endocrine pathology, there is discrepancy between the morphological criteria for malignancy and the biological behaviour of the lesions, which makes it difficult to select appropriate treatment. 
Table 7. Sets of criteria that claim to distinguish reliably benign from malignant adrenocortical neoplasia

\begin{tabular}{lll}
\hline Hough et al. (1979) & Weiss (1984) & Van Slooten et al. (1985) \\
\hline $\begin{array}{l}\text { Diffuse growth pattern } \\
\text { Vascular invasion }\end{array}$ & $\begin{array}{l}\text { High nuclear grade } \\
\text { Mitotic index } \\
(>5 \text { per 10 HPF) }\end{array}$ & Extensive regressive changes \\
Tumour cell necrosis & Atypical mitotic figures & Noss normal structure \\
Broad fibrous bands & Cellular eosinophilia & Nuclear hyperchromasia \\
Capsular invasion & Diffuse growth pattern & Abnormal nucleoli \\
Mitotic index & Necrosis & Mitotic index \\
$\quad(1$ per $10 \mathrm{HPF})$ & (2 per 10 HPF) & Vascular or capsular invasion \\
Pleomorphism & Venous invasion & \\
Tumour mass $>100 \mathrm{~g}$ & Sinusoidal invasion & \\
Raised urinary & Capsular invasion & \\
$\quad$ 17. Ketosteroids & & \\
Abnormal response to ACTH & & \\
Virilism & & \\
Cushing's syndrome & & \\
Weight loss & & \\
\hline
\end{tabular}

In recent decades, three different sets of criteria have been published that claim to distinguish benign from malignant adrenocortical neoplasms reliably (Hough et al. 1979; Weiss 1984; Van Slooten et al. 1985) (Table 7). Although each system has an excellent predictive value, there is not complete concordance among them (Hosaka et al. 1987; Ribeiro et al. 1990). Generally, adrenal carcinoma is defined by necrosis, tumour weight over $100 \mathrm{~g}$, presence of broad bands of fibrosis and a diffuse growth pattern (Page et al. 1985). Nonetheless, only the existence of metastases indicates malignant behaviour for these neoplasms.

On the variables we studied, nuclear form factor (both mean and standard deviation), $5 \mathrm{cER}$, and tumour weight showed significant differences between adenoma and carcinoma. Nuclear form factor and tumour weight both exhibit a similar trend toward maximum value in carcinomas and minimum value in adenomas. This suggests that carcinoma cells present more irregular nuclear forms (form factor further from the value corresponding to a perfect circle) and greater morphological variability (larger standard deviation of the nuclear form factor). This agrees with general criteria for malignant neoplasms, but the diagnostic utility of such characteristics requires additional study. In discriminant analysis, only the mean nuclear form factor retained independent predictive value.

In concurrence with Hosaka and colleagues (Hosaka et al. 1987), we did not find prognostic differences between patients with large carcinomas and those with small tumours, although our series was small and large tumours predominated (average tumour weight $568.3 \mathrm{~g}$ ). Only one patient is alive after 10 years of follow-up; she was a 7-years-old girl that had a tumour weighing $60 \mathrm{~g}$. This case, which showed all the classic histological criteria for the diagnosis of corticoadrenal carcinoma, probably should be reclassified as benign, since our discriminant analysis placed it in the hyperplasia group and it is a small tumour. In a comparative study of adrenocortical carcinoma in children and adults, the size was the only morphological predictor of the biological behaviour in paediatric patients (Cagle et al. 1986). Although the average adrenal weight could differentiate adenomas from carcinomas, we found weight overlap: a case of adenoma weighed $36 \mathrm{~g}$ whereas another of carcinoma had $20 \mathrm{~g}$. This finding was probably due to the broad range of weight present in malignant tumours of the adrenal cortex.

In the hyperplastic glands the entire parenchyma is irregularly proliferated. Of the variables that established statistically significant differences between groups, only the major DNA index differentiated hyperplasia from adenoma; all the variables discriminated between hyperplasia and carcinoma. These results call into question the hyperplasia-adenoma distinction, since the major DNA index lost its independent predictive value in discriminant analysis.

Mean ploidy conserved its independent predictive value, and differentiated hyperplasia from carcinoma. Our results, like those of other studies (Amberson et al. 1987; Hosaka et al. 1987; Joensuu et al. 1989; Rainwater et al. 1989; Venkatesh et al. 1989; Cibas et al. 1990; Padberg et al. 1991) indicate that neither heterogeneity of DNA content, nor aneuploidy are conclusive diagnostic characteristics for malignancy. This contrasts with other studies in which aneuploidy, with diverse proportions of diploid cells, was found only in malignant tumours (Klein et al. 1985; Blowlby et al. 1986). However, the aneuploidy detected in hyperplasia (5 of 10 cases were hypodiploid) is close to that of the normal adrenal gland (where hypodiploidy is seen in 5 of 8 cases studied). Adenoma and carcinoma exhibited hyperdiploidy. In general, mean cytophotometry values (mean ploidy and DNA index) demonstrate that hyperplasias are in the diploid range (mean ploidy 2.11, DNA index 0.98), while both adenoma (mean ploidy 2.41, DNA index 1.31) and carcinoma (mean ploidy 3.05, DNA index 1.39) are in the hyperdiploid range (Fig. 1). Taylor et al. (1987) investigated the value of nuclear DNA analysis in adrenocortical tumours in children and have found abnormal DNA 


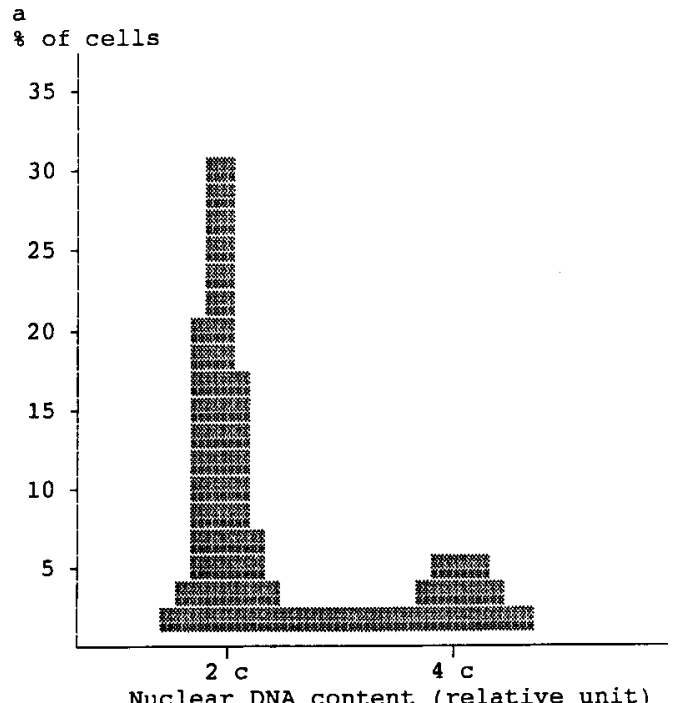

b

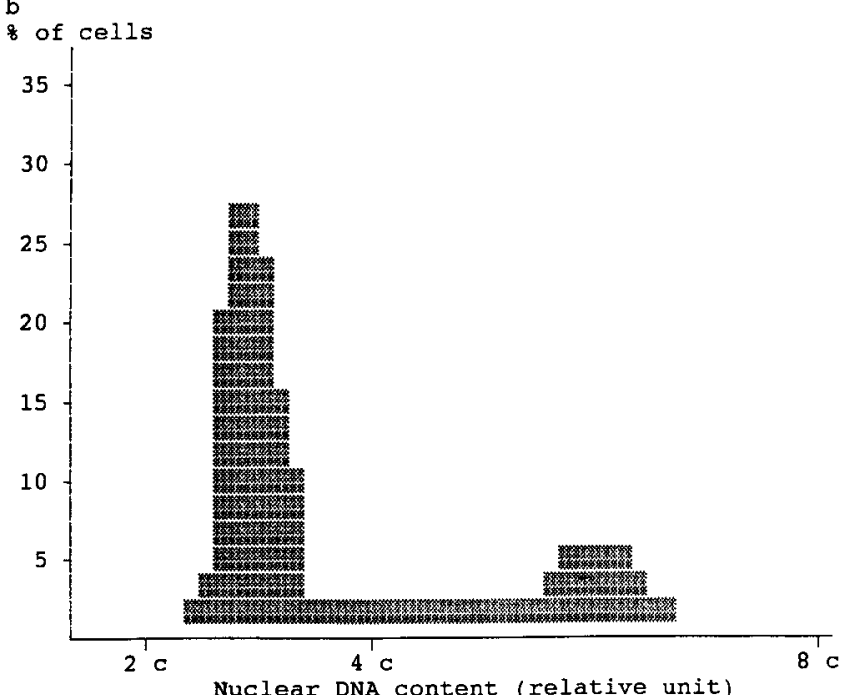

Fig. 1. Histograms of nuclear integral optical density from proliferative adrenal lesions. a) Shows a diploid and b) a hyperdiploid range of DNA content

pattern in all primary lesions that subsequently metastasized.

Finally, keeping in mind the requirements set at the end of the Results, we can classify new cases into diagnostic subgroups with an accuracy of $90 \%$. Although the application of this method requires technical support not available in every laboratory, it has the advantage of simplicity: In each patient only three variables are determined and none of them are clinical. At present, the sets of diagnostic and prognostic criteria for adrenal carcinoma (Hough et al. 1979; Weiss 1984; van Slooten et al. 1985) take into consideration several parameters with varying importance. Both Weiss (1984) and van Slooten et al. (1985) assign the same value to each variable, but Hough et al. (1979), like us, provides each variable with relevance in relation to its relative importance (determined by a mathematical model). With our model, for example, a corticoadrenal lesion of $570 \mathrm{~g}$ weight, form factor (average): 1.822 and ploidy (average): 3.048 relative units gives the highest global discriminant function score in group $\mathrm{C}$, and therefore would be classified as carcinoma.

In conclusion, tumour weight and nuclear form factor differentiate adrenal cortex adenoma from carcinoma, while mean ploidy distinguishes adrenal cortical hyperplasia from carcinoma. The presence of aneuploidy is compatible with both benign histology and biological course.

\section{References}

Amberson JB, Vaughan ED, Gray GH, Naus GJ (1987) Flow cytometric analysis of nuclear DNA from adrenocortical neoplasms. A retrospective study using paraffin-embedded tissue. Cancer 59:2091-2095

Baak JPA, Oort J (1983) A manual of morphometry in diagnostic pathology. Springer, Berlin Heidelberg New York, pp 52-103

Blowlby LS, DeBault LE, Abraham SR (1986) Flow cytometric analysis of adrenal cortical tumor DNA. Relationship between cellular DNA and histopathologic classification. Cancer 58:1499-1505

Böcking A, Auffermann W (1986) Algorithm for DNA-cytophotometric diagnosis and grading of malignancy. Anal Quant Cytol Histol 8:363

Böcking A, Adler CP, Common HD, Hilgarth M, Granzen B, Auffermann W (1984) Algorithm for a DNA-cytophotometric diagnosis and grading of malignancy. Anal Quant Cytol 6:1-8

Cagle PT, Hough AJ, Pysher TJ, Page D, Johnson EH, Kirkland RT, Holcombe JH, Hawkins EP (1986) Comparison of adrenal cortical tumors in children an adults. Cancer 57:2235-2237

Cibas ES, Medeiros LJ, Weinberg DS, Gelb AB, Weiss LM (1990) Cellular DNA profiles of benign and malignant adrenocortical tumors. Am J Surg Pathol 14:948-955

Deitch AD (1966) Cytophotometry of nuclei acid. Introduction to quantitative cytochemistry. Wied GL (ed), Academic Press, New York, pp 327-354

Dressler LG, Barton SA (1989) DNA flow cytometry in solid tumors: practical aspects and clinical applications. Semin Diagn Pathol 6:55-82

Dytch HE, Bibbo M, Puls JA, Wied GL (1986) Software design for an inexpensive practical, microcomputer based DNA cytometry system. Anal Quant Cytol Histol 8:8-18

Friedlanders ML, Hedley DW, Taylor IW (1984) Clinical and biological significance of aneuploidy in human tumours. J Clin Pathol 37:961-974

Hosaka Y, Rainwater LM, Grant CS, Young WF, Farrow GM, Van Heerden JA, Lieber MM (1987) Adrenocortical carcinoma: nuclear deoxyribonucleic acid ploidy studied by flow cytometry. Surgery 102:1027-1034

Hough AJ, Hollifield JW, Page DL, Hartmann WH (1979) Prognostic factors in adrenal cortical tumors. A mathematical analysis of clinical and morphological data. Am J Clin Pathol $72: 390-399$

Joensuu H, Klemi PJ (1988) DNA aneuploidy in adenomas of endocrine organs. Am J Pathol 132:145-151

Joensuu H, Klemi PJ, Eerola E, Touminen J (1986) Influence of cellular DNA content on survival in differentiated thyroid cancer. Cancer 58:2462-2467

Joensuu H, Klemi PJ, Alanen KA (1989) Coexistence of two aneuploid stemlines in benign adenomas. A report of three cases with stemline heterogeneity. Virchows Arch [A] 415:175-180

Klein FA, Kay S, Ratliff JE, White FKH (1985) Flow cytometric determinations of ploidy and proliferation patterns of adrenal neoplasms. An adjunct to histological classification. J Urol 134:862-866 
Montironi R, Scarpelli M, Pisani E, Ansuini G, Marinelli F, Mariuzzi G (1985) Noninvasive papillary transitional cell tumours: karyometric and DNA-content analysis. Anal Quant Cytol Histol 7:337-342

Padberg B-C, Lauritzen I, Achilles E, Holl K, Bressel M, Klöppel G, Dralle H, Shröder S (1991) DNA cytophotometry in adrenocortical tumours: a clinicomorphological study of 66 cases. Virchows Arch [A] 419:167-170

Page DL, DeLelis RA, Hough AJ (1985) Tumors of the adrenal. In: Hartmann WH (ed). Atlas of tumor pathology, 2nd series, fascicle 23. Armed Forces Institute of Pathology, Washington DC, pp 115-161

Puls JA, Bibbo M, Dytch HE, Bartel PH, Wied GL (1986) MicroTICAS: The design of an inepensive video-based microphotometer/computer system for DNA ploidy studies. Anal Quant Cytol Histol 8:17

Rainwater LM, Young WF, Farrow GM (1989) Flow cytometric analysis of deoxyribonucleic and ploidy in benign and malignat aldosterone-producing neoplasms of the adrenal gland. Surg Gynecol Obstet 168:491-496
Ribeiro RC, Neto RS, Schell MJ (1990) Clinical features of adrenocortical carcinoma in children. A study of 40 cases. J Clin Oncol $8: 67-74$

Seckinger D, Sugarbaker E, Frankfurt O (1989) DNA content in human cancer. Application in pathology and clinical medicine. Arch Pathol Lab Med 113:619-626

Taylor SR, Roederer M, Murphy RF (1987) Flow cytometric DNA analysis of adrenocortical tumors in children. Cancer 59:20-59

Tomasi TB (1986) Oncogens and cancer. In Fenoglio-Beiser CM, Weinstein RS, Kaufman N (eds). New concepts in neoplasia as applied to diagnostic pathology. vol 27. International Academy of Pathology. Monographs in Pathology. Williams and Wilkins, Baltimore, pp 59-90

Van Slooten H, Schaberg A, Smeenk D, Moolenaar AJ (1985) Morphologic characteristics of benign and malignant adrenocortical tumors. Cancer 55:766-773

Venkatesh S, Hickey RC, Sellin RV, Fernandez JF, Samaan NA (1989) Adrenal cortical carcinoma. Cancer 64:765-769

Weiss LM (1984) Comparative histologic study of 43 metastasizing and non metastasizing adrenocortical tumors. Am J Surg Pathol $8: 163-169$ 